by Anne-Christine Da Silval, Michael T. Whalen ${ }^{2}$, Jindrich Hladil ${ }^{3}$, Leona Koptikova ${ }^{3}$, Daizhao Chen ${ }^{4}$, Simo Spassov ${ }^{5}$, Frédéric Boulvain ${ }^{1}$, Xavier Devleeschouwer ${ }^{6}$

\title{
Application of magnetic susceptibility as a paleo- climatic proxy on Paleozoic sedimentary rocks and characterization of the magnetic signal - IGCP-580 projects and events
}

1 Pétrologie sédimentaire, B20, Boulevard, du rectorat, 15, Université de Liège, 4000 Liège, Belgium. E-mail : ac.dasilva@ulg.ac.be; fboulvain@ulg.ac.be

2 Dept. of Geology and Geophysics, University of Alaska Fairbanks, Fairbanks, AK 99775, U.S.A. E-mail: mtwhalen@ gi.alaska.edu

3 Institute of Geology AS CR, v.v.i. (Academy of Sciences), Rozvojova 269, 16500 Prague 6. Czech Republic. E-mail: hladil@gli.cas.cz; koptikova@gli.cas.cz.

4 Institute of Geology and Geophysics, Chinese Academy of Sciences, \#19 Beitucheng Xilu, Chaoyang District, Beijing 100029. China. E-mail :dzh-chen@mail.iggcas.ac.cn

5 Geophysical Center of the Royal Meteorological Institute, Environmental magnetism, Rue du Centre de Physique 1, Viroinval (Dourbes), 5670, Belgium. E-mail : simo.spassov@meteo.be

6 Université Libre de Bruxelles CP160/02, Département des Sciences de la Terre et de l'Environnement (DSTE), Laboratoire de Sédimentologie et de Géodynamique des Bassins, 50 Avenue F.D. Roosevelt, 1050 Brussels. Belgium.E-mail : xdevlees@ulb.ac.be

The International Geoscience Program project IGCP580 (started in 2009), focuses on the application of magnetic susceptibility (MS) as a paleoclimatic proxy on Paleozoic sedimentary rocks and on the characterization of the magnetic susceptibility signal. Here we provide a summary of the scientific targets behind the project and a summary of the organized activities. This project concerns three main issues: the first one consists of compiling the available MS data from the different researchers and continuing the collection of new data (with a main focus on the Devonian). The second issue focuses on the identification of the nature and origin of the magnetic minerals carrying MS signal. The last issue concerns the application of MS as a correlation, cyclostratigraphic and paleoclimatic tool. The IGCP580 community consists of 245 researchers, from 45 countries (including Kenya, Namibia, Vietnam, Iran, Uzbekistan, Algeria, Tunisia, Colombia, Nigeria, India, etc.). During the project, we organized five meetings (Belgium, China, Czech Republic, Austria, Canada), three special sessions in international meetings and eight field workshops, as well as various training sessions.

\section{Introduction - Background}

Magnetic susceptibility (MS) measurements are now widely used on sedimentary rocks from the Recent to the Paleozoic. The basic principle of the technique is the following: MS measurements on sedimentary rocks are considered as a proxy for impurities delivered to the sedimentary environment. Although pure sandstones or limestones commonly have very low magnetic response, many terrestrial weathering products, coming from the erosion of continental area, commonly have enhanced MS values. So the measurement of MS in sediment of rocks is considered as a proxy for such detrital input. This relationship is interesting because climatic and eustatic sea level variations will affect the detrital input. A sea-level fall increases the proportion of exposed continent and detrital supply and therefore increases magnetic mineral deposition. Furthermore, higher rainfall or a glaciation will also intensify erosion resulting in an increased input of terrestrial material into sedimentary basins. Bulk MS measurements have been applied on Paleozoic sediments for correlations (Crick et al., 1997, Crick et al., 1999, Ellwood et al., 1999, Ellwood et al., 2000, Gersl \& Hladil, 2004, Da Silva \& Boulvain, 2006, Whalen \& Day, 2008, Riquier et al., 2010) and for reconstruction of sea level (Zhang et al., 2000, Racki et al., 2002, Da Silva \& Boulvain, 2006, Whalen \& Day, 2010) and climatic changes (De Vleeschouwer et al., 2012a). The identification of astronomically driven climatic cycles in the magnetic susceptibility signal has also been used as a metronome to calibrate portions of the geological time scale. Early efforts on the search of orbital cyclicities out of MS data concentrated on relatively young rocks (Weedon et al., 1999, Shackleton et al., 2000) but more recent efforts have pushed this type of analysis into the Mesozoic (Boulila et al., 2008) and the Paleozoic (Ellwood et al., 2007, Ellwood et al., 2011a-b, De Vleeschouwer et al., 2012b, García-Alcalde et al., 2012; Wu et al., 2013; Da Silva et al., 2013).

This IGCP-580 project concerns three main issues: The first one 
consists of compiling available MS data from the different researchers (with a main focus on the Devonian) and to continue to collect new data. The second issue is the main interdisciplinary part of the project and focuses on the identification of the nature and the origin of the magnetic minerals carrying the MS signal. Various processes could influence the measured magnetic susceptibility, such as detrital input (eolian/riverine), early and late diagenesis and in-situ formation of magnetic minerals resulting from bacterial activity. The third and last issue will be, in the light of the obtained results, to support the application of MS in for correlations, cyclostratigraphy and to reconstruct climatic variations, with a main focus on the Devonian.

\section{IGCP-580 working group}

The number of people involved as part of the IGCP-580 community increased regularly from 118 researchers in 2009 to 245 in 2013 (from 45 countries). The main active researchers have contributed and are contributing to major network events (meetings, workshops, field excursions) and/or to the publication record. This means that the visibility of such a research network has a high potential and the interest that it raises in the academic and industrial communities is still increasing. A significant part of the participants to IGCP-580 activities consists of young researchers. During the duration of the program, we have proposed integrated meetings, including when possible, a combination of (1) scientific sessions (poster and oral presentations) allowing active and stimulating discussions between participants, (2) field work campaigns, where local geologists, associated to junior and senior geologists can discuss concrete examples from some of the best Devonian or Carboniferous exposures in the world, (3) field works, where international working teams sampled key target sections in order to provide a multidisciplinary analyses and (4) training sessions, where senior scientists trained young or other senior scientists on all kind of topics related to our program. Numerous papers were also published and a selection of these publications is proposed in the section on IGCP-580 events and activities.

The IGCP-580 communication platform, official webpage (http:/ /www2.ulg.ac.be/geolsed/MS/), includes all the information about the project, participants, meetings, field trips and publications. It also includes the abstract books of the IGCP-580 meetings, as well as the field trip guide books, annual reports and special lectures.

\section{IGCP-580 Events and activities}

\section{9 - Opening year and first results - IGCP-580 meeting in Liège, Belgium}

The opening meeting took place in Liège, Belgium $\left(2-6^{\text {th }}\right.$ December 2009), organized by A.C. Da Silva and F. Boulvain (Liège University), with 44 participants from 18 countries (Fig. 1). The program included two days of scientific sessions (23 talks, 3 keynote speakers and 11 posters; Da Silva \& Boulvain, 2010b) and another two days of field trip provided an overview through the sedimentology and magnetic susceptibility signal of the Frasnian reefs and mounds in Belgium (Fig. 2; Boulvain \& Da Silva, 2010). Selected high-quality outcrops provided a good illustration of the palaeoenvironments, ranging from supratidal (paleosols, restricted lagoons) to open marine (carbonate mounds inbedded in shales) paleoenvironments. Detailed architecture of the platform and carbonate mounds was discussed and linked to sea-level variations. The use of magnetic susceptibility for high precision stratigraphic correlation and for bathymetric reconstruction was illustrated by several examples.

Some of the major scientists in the field (B.B. Ellwood, M. Chadima, X. Devleeschouwer and S. Spassov) offered one day of training during the Liège meeting, covering all the techniques related to the application of magnetic susceptibility in environmental studies. During the poster and lunch sessions, we also had magnetic susceptibility measurement device demonstrations by M. Chadima from Agico Inc. (Czech Republic) and L. Letourneur from Bartington Instruments (U.K.). During the last day of the meeting, S. Spassov offered a visit to the Geophysical Center of the Belgian Royal Meteorological Institute in Dourbes, with an overview of the different magnetic facilities (Fig. 3).

First results were published in high quality peer reviewed publications and were mostly related to the application of MS, with a focus on the impact of sea-level variations and depositional setting on MS signal from the Devonian from Belgium (Da Silva et al., 2009a) and Canada (Da Silva et al., 2009b); on the influence of atmospheric dust during the punctata conodont Zone interval in the Czech Republic (Hladil et al., 2009) and on the influence of volcanic admixture on the MS signal from Devonian carbonates in Portugal (Machado et al., 2009).

A special issue in the peer reviewed Open Access journal Geologica Belgica was released in 2010 entitled "Magnetic susceptibility, correlations and Paleozoic environments", edited by Da Silva and Boulvain, following the meeting in Liège (Fig. 4; http:/ /popups.ulg.ac.be/Geol/sommaire.php?id=3034). It includes 11 papers (Babek et al., 2010, Boulvain et al., 2010, Da Silva \& Boulvain, 2010a, Da Silva et al., 2010, Debacker et al., 2010, Devleeschouwer et al., 2010, Hladil et al., 2010a, Hladil et al., 2010b, Koptíková et al., 2010b, Michel et al., 2010, Sliwinski et al., 2010), as well as the field trip guide book and abstract book of the 2009 meeting in Liège, Belgium (Boulvain \& Da Silva, 2010, Da Silva \& Boulvain, 2010b).

\section{0 - IGCP-580 meeting in Guilin, China and a special session in Paris, France}

The second IGCP-580 meeting (D. Chen and A.C. Da Silva) was organized in Guilin, China ( $25^{\text {th }}$ of November $-4^{\text {th }}$ of December 2010$)$, with 52 participants, from 8 countries (Fig. 5). During the scientific session, 12 oral presentations were given and 8 posters were presented (Chen \& Da Silva, 2010). Then two days of field trip were organized by D. Chen (Fig. 6-7) affording all participants to have an overview of the stratigraphy and sedimentology of Devonian to Carboniferous carbonates around Guilin, South China (Chen, 2010). Some key sections recording the paleoenvironmental changes around the Givetian-Frasnian, Frasnian-Famennian and the Devonian Carboniferous boundaries were visited. The opportunity was also given to visit the $240 \mathrm{~m}$ long Reed Flute Cave. On the second field trip day, the spectacular karstic landscapes (Fig. 8) along the Li river were inspected by boat, showing impressively how depositional facies of the Devonian limestones controlled the scenic karstic topography. Furthermore, several outcrops of basinal deposits were visited, including the Givetian-Frasnian and Frasnian-Famennian boundaries. Afterwards, a four days sampling campaign was organized, with participation of four international teams including scientists from Belgium, China, Czech Republic, India, Poland, Senegal and U.S.A., 

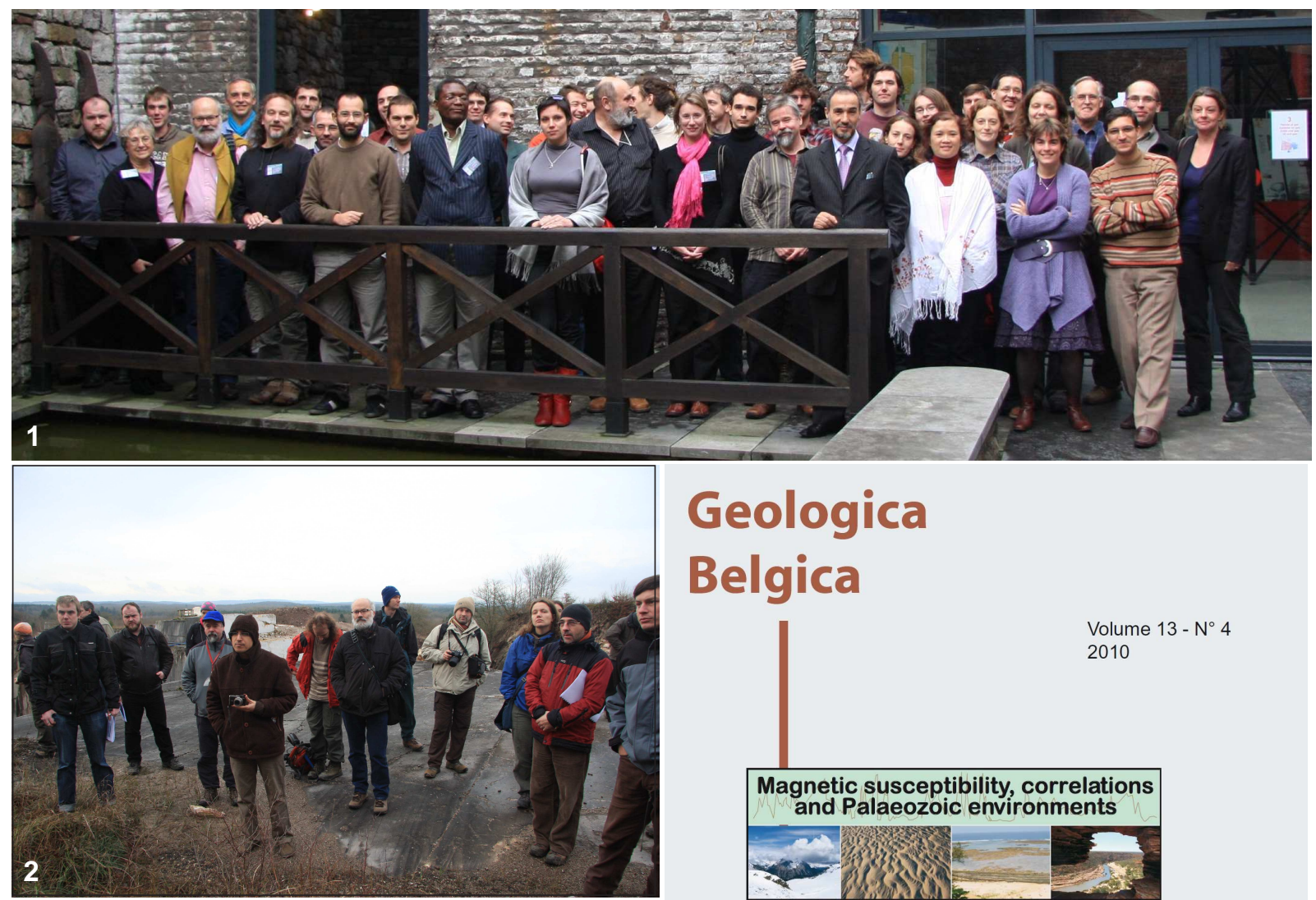

\section{Geologica Belgica}
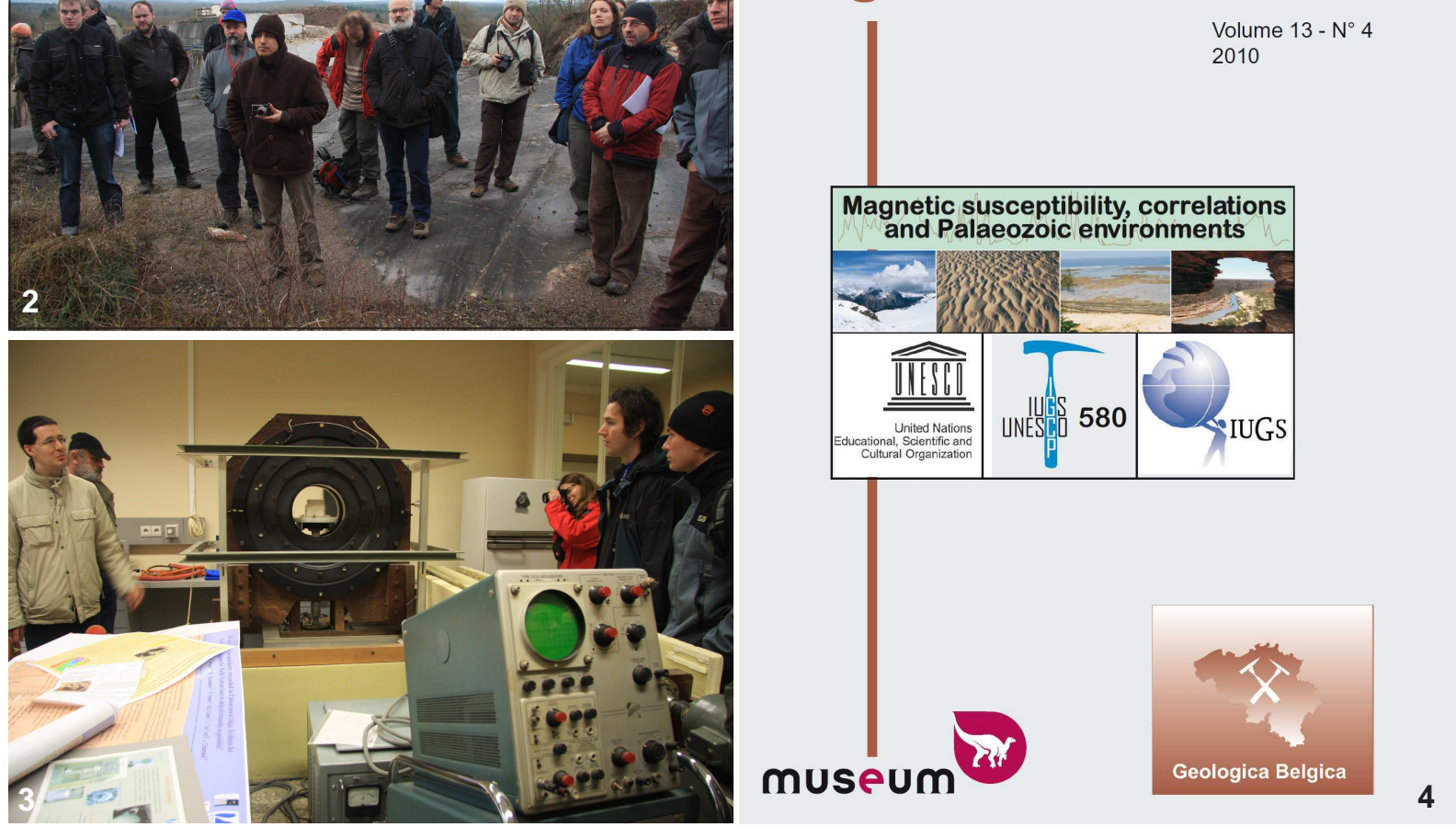

Figures (1-3) 2009, First IGCP-580 meeting in Liège, Belgium. (1) conference photo taken in the courtyard of the Metallurgy museum in which the meeting was held. (2) post meeting field trip in the Frasnian of Belgium (Hautmont quarry). (3) post meeting visit of Dourbes Geophysical Center of the Royal Meteorological Institute. (4) 2010, cover of the special issue of Geologica Belgica published after the Liege meeting

as well as $8 \mathrm{PhD}$ students or young researchers from China. These teams worked on 7 sections, covering the period between the Givetian and the Carboniferous.

In 2010, X. Devleeschouwer and L. Riquier also organized a special session at STRATI2010 - $4^{\text {th }}$ French Congress on Stratigraphy (Université Pierre et Marie Curie, August 30 - September 2, 2010), entitled "Utilization of magnetic susceptibility in the sedimentary record". This session included 2 posters and 8 talks.

Papers on various topics were also published in international peerreviewed journals concerning: the identification of sea level variations through the application of MS, and the correlation of Devonian sections from Canada (Whalen and Day, 2010), the connection between different proxy data such as spectral reflectance, Gamma
Ray Spectrometry (GRS) and MS measurements on the Devonian from Czech Republic (Koptíková et al., 2010a, Vacek et al., 2010), the influence of diagenesis and detrital inputs on the MS signal at the Frasnian-Famennian boundary from North Africa and Western Europe (Riquier et al., 2010), etc.

\section{1 - IGCP-580 meeting in Prague, Czech} Republic and a field workshop in Austria

During this year, a very strong collaboration was initiated with the new IGCP-596 project, related to climate change and biodiversity patterns in the Mid-Paleozoic. In the framework of this strong collaboration, a field workshop was organized in the Carnic Alps 

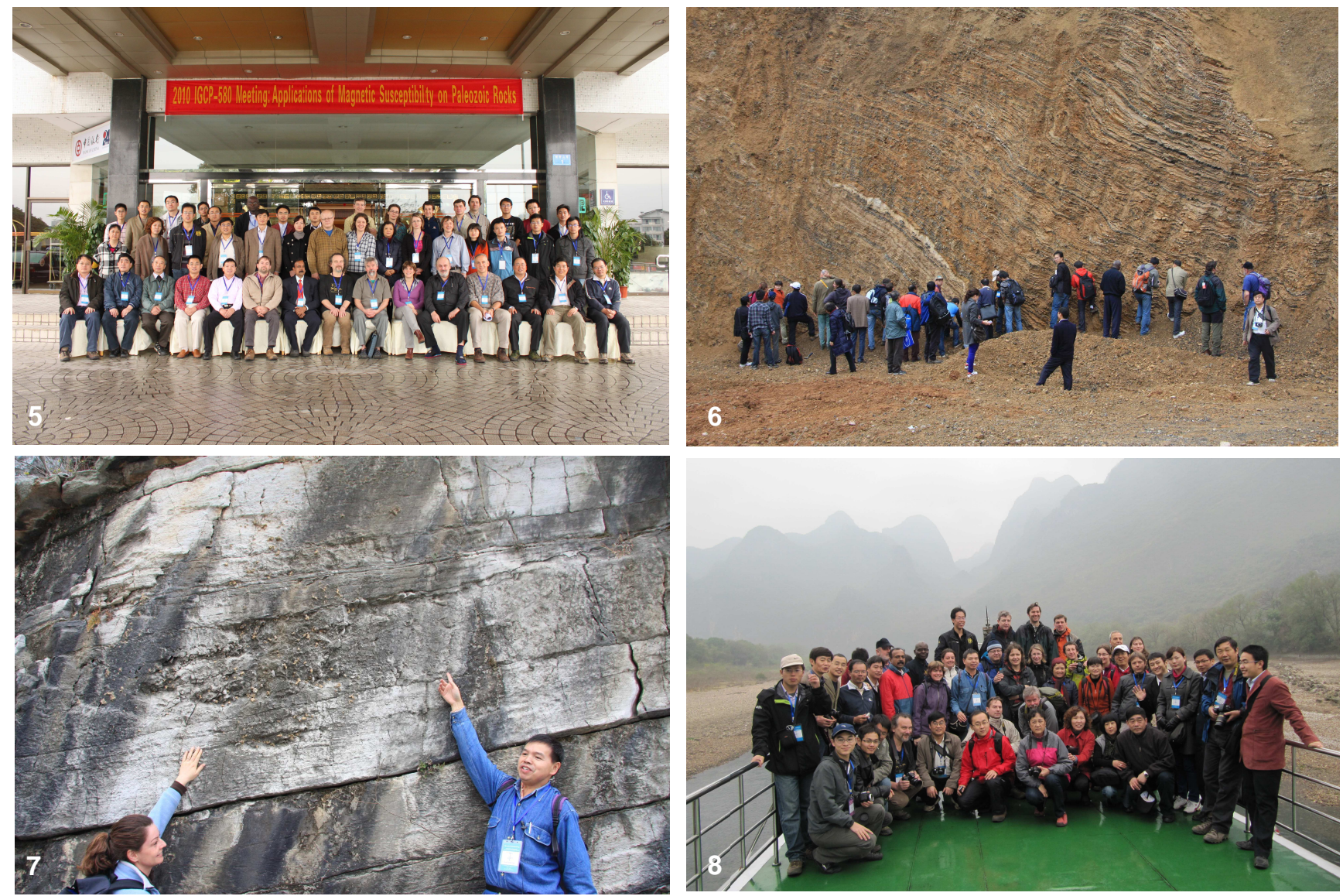

Figures (5-8) 2010. IGCP-580 meeting in Guilin, China, (5) conference photo taken in front of the hotel. (6) post conference field trip, photo taken in a quarry of Frasnian bedded cherts at Baisha, Yangshuo County, Guilin. (7) post conference field trip, D. Chen showing the Frasnian-Famennian boundary at the Detergent Factory section. (8) post conference field trip, cruise on the Li River, picture in front of the scenic karstic landform in the Devonian

with a team of 8 participants from both IGCPs (from Belgium, Austria and Italy) working together on the sampling of different Devonian sections. Furthermore, participants from our IGCP-580 presented four talks (including one keynote) and two posters at the opening meeting of IGCP-596.

The third IGCP-580 meeting was held in Prague, Czech Republic, organized by L. Koptikova (now Chadimová) and J. Hladil (12-18 ${ }^{\text {th }}$ October 2011), with 51 participants from 15 countries (Fig. 9). During the two days of scientific session, 19 talks and 7 posters (Koptikova et al., 2011) were presented. Five training lectures were given by specialists from different scientific fields, sharing their knowledge and experience concerning magnetic particles in different environments, study and synthesis of nanoparticles and it applications in biotechnologies, mapping and identifying of anthropogenic pollution, processing and data treatment (F. Hrouda, I. Šafaøík, E. Petrovský, A. Kapièka, M. Chadima). Afterwards, one day of field trip was organized by J. Hladil, L. Koptikova and L. Slavik (Fig. 10-12) to provide all participants an overview of the Silurian to Devonian in the Barrandian area (Hladil et al., 2011a). The last three days were dedicated to team work sampling, with two international teams, working on four sections from the Barrandian Area (Upper Silurian sections in the Prague Synform, supervised by J. Hladil, L. Koptikova) and the Moravian Karst (Frasnian-Famennian; Fig. 13 and Devonian-Carboniferous boundary, supervised by O. Babek and S. Slechta).
A training session was also proposed at the University of Manizales Caldas (Colombia), by A.C. Da Silva and organized by A. Pardo-Trujillo. It concerned the application of magnetic susceptibility as an environmental proxy and was foreseen for master students as well as for interested researchers. This training session was hold within the framework of a new project launched by A. Pardo-Trujillo on the Cenozoic of Northern Columbia, including magnetic susceptibility measurements.

This year, papers were published in major peer-reviewed journals focusing on the link between facies, rock magnetism and the MS signal of the Devonian in Belgium, in order to identify its origin (Casier et al., 2011), to make connections between MS, GRS and geochemical proxy data in the Devonian of Czech Republic (Koptíková, 2011, Vacek, 2011) and to perform correlations between Uzbekistan and Prague Synform with MS log and their dynamic time warping alignment (Hladil et al., 2011b), etc.

\section{2 - IGCP-580 meeting in Graz, Austria and two} field workshops and two special sessions

The fourth IGCP-580 meeting was held in Graz $\left(20-30^{\text {th }}\right.$ June 2012), organized by T. Suttner, E. Kido and W. Piller. Within the framework of this meeting we brought together scientists that apply geophysical methods (mostly GRS and MS) working on different time slices. During the two days of the meeting, 17 talks and 8 posters 

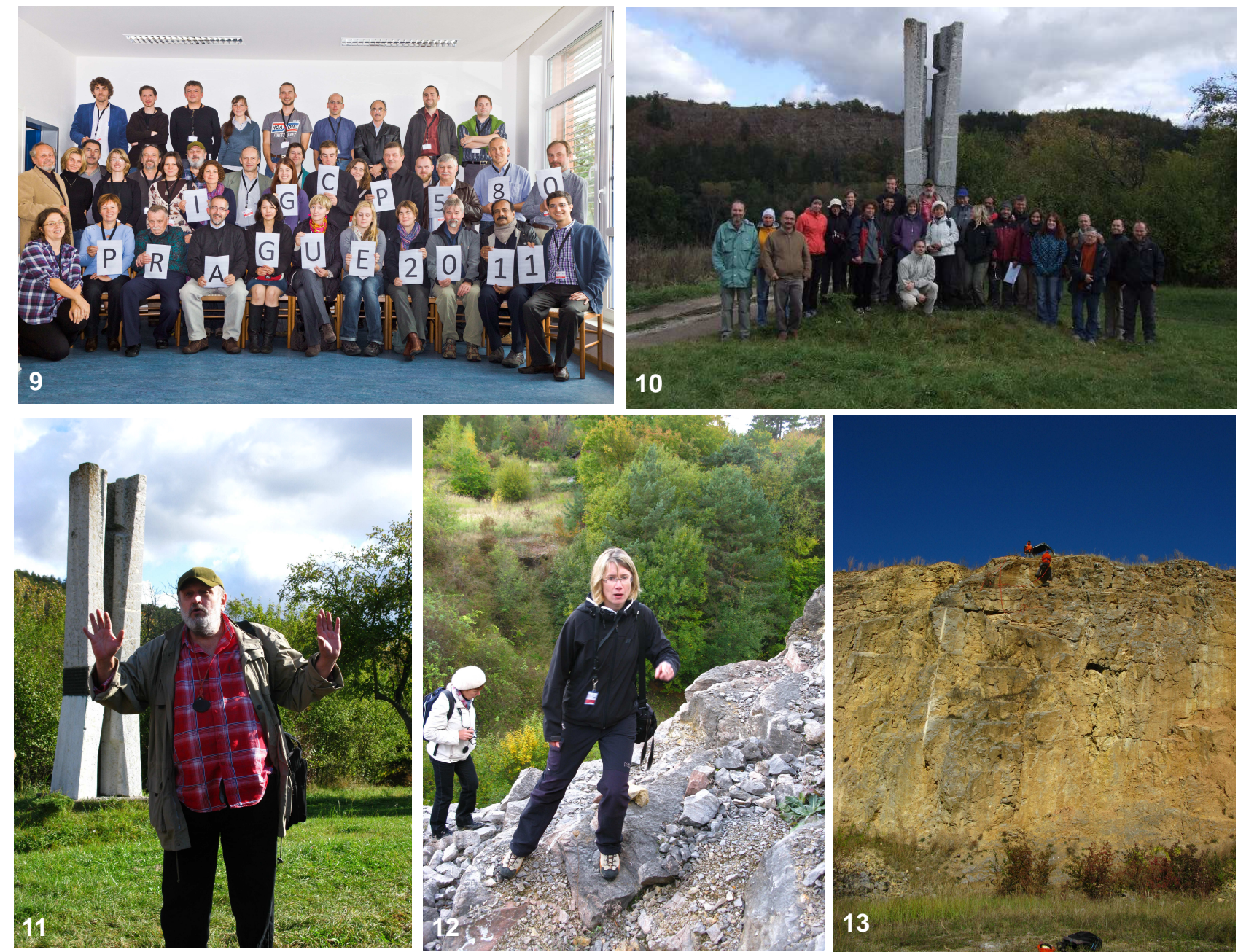

Figures (9-12) 2011, IGCP-580 meeting in Prague, Czech Republic, (9) conference photo taken in the Institute of Geology AS CR, v.v.i. (Czech Academy of Science). (10) post-conference field trip, leaders L. Slavik, J. Hladil and L. Koptikova. Group picture in front of the Klonk section (stratotype of the GSSP Silurian Devonian boundary). (11-12) post-conference field trip, leaders L. Slavik, J. Hladil and L. Koptikova. (13) 2011, IGCP-580 meeting in Praha, Czech Republic, post-conference sampling workshop, Lesni quarry (leaders: O. Babek and S. Slechta).

were presented (Kido et al., 2012), by 26 participants from 12 countries (Fig. 14). After the scientific sessions, a two days field trip allowed the participants to have a good overview of the Paleozoic near Graz (Fig. 15); the Carboniferous in the Nassfeld Area and the Ordovician to Carboniferous succession around Lanza (Fig. 16). One day field work allowed the sampling of Rio Malinfier West section (Silurian-Devonian boundary; Fig. 17) (Corradini et al., 2012).

Two field workshops were also organized, both in collaboration with IGCP-596. The Eifel Workshop in Germany (April 2012) involved 5 scientists from Germany, Belgium and Austria. It focused on the sampling of the Blankenheim section, cutting through the Eifelian Givetian boundary. The second workshop, in the Carnic Alps (July 2012) included researchers from Belgium, Austria and Italy, allowing the sampling of four Devonian sections.

A special session was organized, in conjunction with IGCP-596 and the subcommission of the Devonian Stratigraphy, at the $34^{\text {th }}$ International Geological Congress, in Brisbane, Australia (August 2012). The session was chaired by P. Königshof and T. Suttner and dealt with climate change and biodiversity patterns in the MidPalaeozoic (12 talks, 5 posters). A special session was also organized at the $4^{\text {th }}$ International Geologica Belgica meeting - Moving plates and melting icecaps, processes and forcing factors in geology, Brussels, Belgium (September 2012). The session entitled "Magnetic susceptibility: a high resolution stratigraphic tool during greenhouse periods" was chaired by A.C. Da Silva and L. Koptikova and included 6 talks and 4 posters.

Papers were published in peer reviewed journals, concerning the origin of the MS signal in the Devonian of Belgium and the impact of diagenesis (Da Silva et al., 2012), on the application of MS and other proxy data as a tool for correlation and paleoenvironmental reconstruction (Da Silva \& Boulvain, 2012); on the cyclostratigraphy and climate evolution during the Givetian of Belgium (De Vleeschouwer et al., 2012a); on the cyclostratigraphy and duration of the Frasnian in Canada (De Vleeschouwer et al., 2012b) and the relationship between MS and detrital input in Canada (Sliwiñski et al., 2012), on the link between GRS, carbon isotopes and MS with climatic variations during the Silurian of Poland (Kozowski and Sobieñ, 2012), and on the connection between $\delta^{13} \mathrm{C}_{\text {org }}$ and MS at the Paleocene/Eocene boundary of Spain (Storme et al., 2012), etc. 

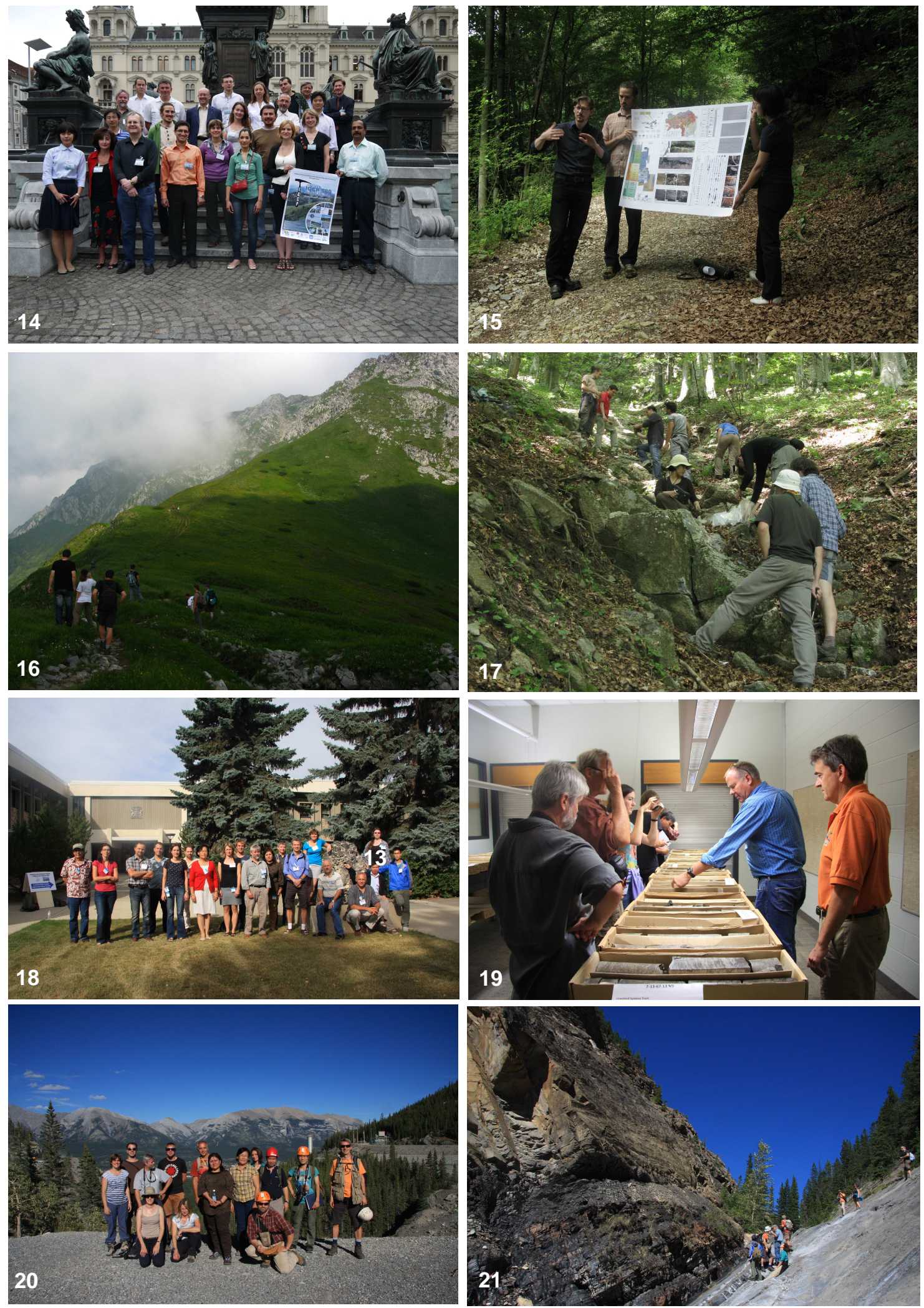

Figures 14-17. 2012, IGCP-580 meeting in Graz, Austria, (14) conference photo taken at the main square of Graz. (15) post conference field trip, T. Suttner giving explanations on the Palaeozoic of Graz. (16) post conference field trip,Carnic Alps, Italy, near Lanza. (17) post conference field trip, Carnic Alps, Italy, Rio Malinfer section.

Figures 18-21. 2013, IGCP-580 and 596 meeting in Calgary, Canada, (18) conference picture in front of the Geological Survey of Canada. (19) Core workshop proposed by K. Potma and J. Weissenberger.focussing on the Devonian of subsurface from Alberta (20) post conference field trip, near the top of Grassi Lakes section, Canadian Rockies, Alberta. (21) post conference field trip, Devonian-Carboniferous boundary, Jura Creek, Canadian Rockies, Alberta. 


\section{3 - IGCP-580 meeting in Calgary, Canada}

The annual meeting of 2013 was organized in conjunction with the group IGCP-596 and was held in Calgary $\left(27^{\text {th }}\right.$ August to $4^{\text {th }}$ September 2013). During the two first days of this IGCP 580-596 Meeting, 20 talks (including 3 keynotes) and 6 posters were presented (Whalen et al., 2013), by 27 participants from 8 countries (Fig. 18). The scientific session was followed by one day training core workshop examining Devonian rocks of the Alberta subsurface, led by K. Potma and J. Weissenberger (Potma \& Weissenberger 2013; Fig. 19). The following two days were devoted to field excursions for examining the Devonian at Grassi Lakes (Fig. 20) and the DevonianCarboniferous boundary at Jura Creek (Fig. 21). The meeting ended up with two days of sampling of a Devonian core at the Core Research Centre in Calgary.

The magnetic susceptibility evolution of different marine sediment sections was compared with the sedimentological evolution and it was showed in different cases that MS is strongly influenced by sea level variations and that it can be used for correlations between different sections, mostly in the same basin (Babek et al., 2013; Bertola et al., 2013; Da Silva et al., 2013; Grabowski et al., 2013; Michalik et al., 2013; Pas et al., 2013). A close link between MS and Al, Zr, Ti and other lithogenic elements was also observed on different sedimentary successions, implying that MS can be interpreted as a proxy for detrital inputs (Da Silva et al., 2013; Grabowski et al., 2013; Pas et al., 2013). Although in a few cases an influence of diagenesis was noticed, and this influence would lead to the lost of primary depositional information (Babek et al., 2013: Da Silva et al., 2013).

\section{Conclusions}

The IGCP-580 project intends to apply magnetic susceptibility measurements to sedimentary rocks, in order to get insight into paleoenvironmental and paleo-climatic variations during the Palaeozoic (with a focus on the Devonian). In this respect, the project also focuses on a better understanding of the origin of the MS signal and of the influence of various parameters such as sedimentary setting, eolian supplies and diagenesis. During the 5 years of the project, 5 annual meetings were organized (Belgium, China, Czech Republic, Austria and Canada) and 3 special sessions at international meetings and 8 field workshops. The program included numerous of students or young researchers for whom, various training activities were organized.

\section{Acknowledgements}

We would like to acknowledge all participants to any kind of IGCP-580 event (meetings, field works, special sessions, or publications). We also thank IGCP-596 for successful collaborations.

\section{References}

Babek, O., Kalvoda, J., Aretz, M., Cossey, P.J., Devuyst, F.X., Herbig, H.G. and Sevastopulo, G., 2010, The correlation potential of magnetic susceptiblility and outcrop Gamma-Ray logs at Tournaisian-Viséan boundary sections in Western Europe. In: Da Silva, A.C., Boulvain, F. (eds.) Magnetic susceptibility, correlations and Palaeozoic environments, v. 13 , no. 4, pp. 291-308.

Bábek, O., Kalvoda, J., Cossey, P., Šimíèek, D., Devuyst, F.-X. and Hargreaves, S., 2013, Facies and petrophysical signature of the Tournaisian/Viséan (Lower Carboniferous) sea-level cycle in carbonate ramp to basinal v. 284-285, pp. 197-213.

Bertola, C., Boulvain, F., Da Silva, A.C. and Poty, E., 2013, Sedimentology and magnetic susceptibility of Mississippian (Tournaisian) carbonate sections in Belgium Bulletin of Geosciences, v. 88, pp. 69-82.

Boulila, S., Galbrun, B., Hinnov, L.A. and Collin, P.-Y., 2008, High-resolution cyclostratigraphic analysis from magnetic susceptibility in a Lower Kimmeridgian (Upper Jurassic) marl-limestone succession (La Méouge, Vocontian Basin, France). Sedimentary Geology, v. 203, pp. 54-63.

Boulvain, F. and Da Silva, A.C., 2010, Frasnian reefs, mounds and atolls from Belgium: sedimentology and magnetic susceptibility - a field trip guide book. In: Da Silva, A.C., and Boulvain, F., eds, Magnetic susceptibility, correlations and palaeoenvironments: Geologica Belgica, pp. 483-496.

Boulvain, F., Da Silva, A.C., Mabille, C., Hadil, J., Gersl, M., Koptikova, L. and Schnabl, P., 2010, Magnetic susceptibility correlation of km-thick Eifelian-Frasnian sections (Ardenne-Moravian karst). In: Da Silva, A.C., Boulvain, F., eds, Magnetic susceptibility, correlations and Palaeozoic environments. Geologica Belgica, v. 13, no. 4, pp. 309-318.

Casier, J.G., Devleeschouwer, X., Petitclerc, E. and Préat, A., 2011, Ostracods, rock facies and magnetic susceptibility of the Hanonet Formation / TroisFontaines Formation boundary interval (Early Givetian) at the Mont d'Haurs (Givet, France). Bulletin de l'Institut Royal des Sciences Naturelles de Belgique, v. 81, pp. 63-96.

Chen, D., 2010, Guide book for field excursion - Devonian-Carboniferous Carbonates around Guilin, South China: Stratigraphy and Sedimentology, $29 \mathrm{pp}$.

Chen, D. and Da Silva, A.C., 2010, IGCP-580 Meeting - Application of magnetic susceptibility on Paleozoic rocks. Meeting programme and Abstracts. Guilin, China, 34 pp.

Corradini, C., Pondrelli, M., Corriga, M.G., Simonetto, L., Kido, E., Suttner, T.J., Spalletta, C. and Carta, N., 2012, Geology and stratigraphy of the Cason di Lanza area (Mount Zermula, Carnic Alps, Italy. In: Kido, E., Suttner, T.J., Piller, W.E., Da Silva, A.C., Corradini, C., and Simonetto, L., eds, IGCP 580 - 4th Annual Meeting (24-30/06/2012). B.I.E., KarlFranzens-Universität Graz, Graz, pp. 83-103.

Crick, R.E., Ellwood, B.B. and El Hassani, A., 1999, The Magnetosusceptibility event and cyclostratigraphy used in geological correlation of Middle Devonian rocks from Morocco - European Union Geosciences 9th Annual Meeting Strasbourg, France. Abstract: Supplement no.1. Terra Nova, v. 9, pp. 312.

Crick, R.E., Ellwood, B.B., El Hassani, A., Feist, R. and Hladil, J., 1997, Magnetosusceptibility event and cyclostratigraphy (MSEC) of the Eifelian - Givetian GSSP and associated boudary sequences in north Africa and Europe. Episodes, v. 20, pp. 167-175.

Da Silva, A.-C. and Boulvain, F., 2006, Upper Devonian carbonate platform correlations and sea level variations recorded in magnetic susceptibility. Palaeogeography, Palaeoclimatology, Palaeoecology, v. 240, pp. 373-388.

Da Silva, A.C. and Boulvain, A., 2010a, Magnetic susceptibility, correlations and Palaeozoic environments: foreword. In: Da Silva, A.C., Boulvain, F., eds, Magnetic susceptibility, correlations and palaeoenvironments. Geologica Belgica, v. 13, no. 4, pp. 287-290.

Da Silva, A.C. and Boulvain, F., 2010b, Abstract of the first IGCP - 580 meeting Liège, Belgium, Geologica Belgica, v. 13, no. 4, p. 37.

Da Silva, A.C. and Boulvain, F., 2012, Analysis of the Devonian (Frasnian) platform from Belgium: amulti-faceted approach for basin evolution reconstruction. Basin Research, v. 24, pp. 338-356.

Da Silva, A.C., De Vleeschouwer, D., Boulvain, F., Claeys, P., Fagel, N., Humblet, M., Mabille, C., Michel, J., Sardar Abadi, M., Pas, D. and Dekkers, M.J., 2013, Magnetic susceptibility as a high-resolution correlation tool and as a climatic proxy in Paleozoic rocks - Merits and pitfalls: Examples from the Devonian in Belgium. Marine and Petroleum Geology, v. 46, pp. 173-189.

Da Silva, A.C., Dekkers, M.J., Mabille, C. and Boulvain, F., 2012, Magnetic signal an its relationship with paleoenvironments and diagenesis examples from the Devonian carbonates of Belgium. Studia Geophysica and Geodaedica, v. 56, pp. 677-704. 
Da Silva, A.C., Mabille, C. and Boulvain, F., 2009a, Influence of sedimentary setting on the use of magnetic susceptibility: examples from the Devonian of Belgium. Sedimentology, v. 56, pp. 1292-1306.

Da Silva, A.C., Potma, K., Weissenberger, J.A.W., Whalen, M.T., Mabille, C. and Boulvain, F., 2009b, Magnetic susceptibility evolution and sedimentary environments on carbonate platform sediments and atolls, comparison of the Frasnian from Belgium and from Alberta. Sedimentary Geology, v. 214, pp. 3-18.

Da Silva, A.C., Yans, J. and Boulvain, F., 2010, Sedimentology and magnetic susceptibiliy during the "punctata" event of the Ardenne area (Belgium): identification of severe and rapid sea level fluctuations. In: Da Silva, A.C., Boulvain, F., eds, Magnetic susceptibility, correlations and Palaeozoic environments. Geologica Belgica, v. 13, no.4, pp. 319-332.

De Vleeschouwer, D., Da Silva, A.C., Boulvain, F., Crucifix, M. and Claeys, P., 2012a, Precessional and half-precessional climate forcing of MidDevonian monsoon-like dynamics. Climate of the Past, v. 7, pp. 14271455 .

De Vleeschouwer, D., Whalen, M.T., Day, J.E. and Claeys, P., 2012b, Cyclostratigraphic calibration of the Frasnian (Late Devonian) time-scale (Western Alberta, Canada). Geological Society of America Bulletin, v. 124, pp. 928-942.

Debacker, T., Sintubin, M. and Robion, P., 2010, On the use of magnetic techniques for stratigraphic purposes: examples from the Lower Palaeozoic Anglo-Brabant Deformation Belt (Belgium). In: Da Silva, A.C., Boulvain, F., eds, Magnetic susceptibility, correlations and Palaeozoic environments, Geologica Belgica, v. 13, no. 4, pp. 333-350.

Devleeschouwer, X., Petitclerc, E., Spassov, S. and Préat, A., 2010, The Givetian-Frasnian boundary at Nismes parastratotype (Belgium): the magnetic susceptibility signal controlled by ferromagnetic minerals In: Da Silva, A.C., Boulvain, F., eds, Magnetic susceptibility, correlations and Palaeozoic environments, Geologica Belgica, v. 13, no. 4, pp. pp. 351-366.

Ellwood, B.B., Algeo, T.J., El Hassani, A., Tomkin, J.H. and Rowe, H.D., 2011a, Defining the timing and duration of the Kaèa Interval within the Eifelian/Givetian boundary GSSP, Mech Irdane, Morocco, using geochemical and magnetic susceptibility patterns. Palaeogeography, Palaeoclimatology, Palaeoecology, v. 304, pp. 74-84.

Ellwood, B.B., Crick, R.E. and El Hassani, A., 1999, Magnetosusceptibility event and cyclostratigraphy (MSEC) method used in geological correlation of Devonian rocks from Anti-Atlas Morocco. The American Association of Petroleum geologists, Bulletin, v. 83, 1119-1134.

Ellwood, B.B., Crick, R.E., El Hassani, A., Benoist, S.L. and Young, R.H., 2000, Magnetosusceptibility event and cyclostratigraphy method applied to marine rocks : detrital input versus carbonate productivity. Geology, v. 28 , pp. $1135-1138$.

Ellwood, B.B., Tomkin, J.H., El Hassani, A., Bultynck, P., Brett, C.E., Schindler, E., Feist, R. and Bartholomew, A.J., 2011b, A climate-driven model and development of a floating point time scale for the entire Middle Devonian Givetian Stage: A test using magnetostratigraphy susceptibility as a climate proxy. Palaeogeography, Palaeoclimatology, Palaeoecology, v. 304, pp. 85-95.

Ellwood, B.B., Tomkin, J.H., Richards, B.C., Benoist, S.L. and Lambert, L.L., 2007, MSEC data sets record glacially driven cyclicity: Examples from the arrow canyon Mississippian-Pennsylvanian GSSP and associated sections. Palaeogeography, Palaeoclimatology, Palaeoecology, v. 255, pp. 377-390.

García-Alcalde, J.L., Ellwood, B.B., Soto, F., Truyóls-Massoni, M. and Tomkin, J.H., 2012, Precise timing of the Upper Taghanic Biocrisis, Geneseo Bioevent, in the Middle-Upper Givetian (Middle Devonian) boundary in Northern Spain using biostratigraphic and magnetic susceptibility data sets. Palaeogeography, Palaeoclimatology, Palaeoecology, v. 313-314, pp. 26-40.

Geršl, M. and Hladil, J., 2004, Gamma-ray and magnetic susceptibility correlation across a Frasnian carbonate platform and the search for "punctata" equivalents in stromatoporoid-coral limestone facies of Moravia. Geological Quarterly, v. 48, pp. 283-292.
Grabowski, J., Schnyder, J., Sobieñ, K., Koptíková, L., Krzemiñski, L., Pszczó3kowski, A., Hejnar, J. and Schnabl, P., 2013, Magnetic susceptibility and spectral gamma logs in the Tithonian-Berriasian pelagic carbonates in the Tatra Mts (Western Carpathians, Poland): Palaeoenvironmental changes at the Jurassic/Cretaceous boundary. Cretaceous Research, v. 43, pp. 1-17.

Hladil, J., Cejchan, P., Babek, O., Koptikova, L., Navratil, T. and Kubinova, P., 2010a, Dust - A geology-orientated attempt to reappraise the natural components, amounts, inputs to sediment, and importance for correlation purposes. In: Da Silva, A.C., Boulvain, F., eds, Magnetic susceptibility, correlations and Palaeozoic environments. Geologica Belgica, v. 13, no.4, pp. 13, 367-384.

Hladil, J., Koptikova, L., Galle, A., Sedlacek, V., Pruner, P., Schnabl, P., Langrova, A., Babek, O., Frana, J., Hladikova, J., Otava, J. and Gersl, M., 2009. Early Middle Frasnian platform reef strata in the Moravian Karst interpreted as recording the atmospheric dust changes: the key to understanding perturbations in the punctata conodont Zone. Bulletin of Geosciences, v. 84, pp. 75-106.

Hladil, J., Koptíková, L. and Slavík, L., 2011a, Field Trip Barrandian (selected outcrops of Palaeozoic limestones). The 2011 Miroslav Krs Conference: Time, Magnetism, Records, Systems and Solutions. Guidebook. Institute of Geology AS CR Praha, 60pp.

Hladil, J., Slavik, L., Vondra, M., Koptikova, L., Cejchan, P., Schnabl, P., Adamovic, J., Vacek, F., Vich, R., Lisa, L. and Lisy, P., 2011b, PragianEmsian successions in Uzbekistan and Bohemia: magnetic susceptibility logs and their dynamic time warping alignment. Stratigraphy, v. 8, pp. 217-235.

Hladil, J., Vondra, M., Cejchan, P., Vich, R., Koptikova, L. and Slavik, L., $2010 \mathrm{~b}$, The dynamic time-warping approach to comparison of magneticsusceptibility $\log$ s and application to lower Devonian calciturbidites (Prague Synform, Bohemian Massif). In: Da Silva, A.C., Boulvain, F., eds, Magnetic susceptibility, correlations and Palaeozoic environments. Geologica Belgica, v. 13, no.4, pp. 385-406.

Kido, E., Suttner, T.J., Piller, W.E., Da Silva, A.C., Corradini, C. and Simonetto, L., eds, 2012, IGCP 580, Magnetic Susceptibility and GammaRay Spectrometry through time. Abstracts book IGCP-580, 4th annual meeting, Berichte des Institutes für Erdwissenschaften, Karl-FranzensUniversität Graz, Graz, Austria pp. 108.

Koptíková, L., 2011, Precise position of the Basal Choteè event and evolution of sedimentary environments near the Lower-Middle Devonian boundary: The magnetic susceptibility, gamma-ray spectrometric, lithological, and geochemical record of the Prague Synform (Czech Republic). Palaeogeography, Palaeoclimatology, Palaeoecology, v. 304, pp. 96-112.

Koptíková, L., Bábek, O., Hladil, J., Kalvoda, J. and Slavík, L., 2010a, Stratigraphic significance and resolution of spectral reflectance logs in Lower Devonian carbonates of the Barrandian area, Czech Republic; a correlation with magnetic susceptibility and gamma-ray logs. Sedimentary Geology, v. 225, pp. 83-98.

Koptikova, L., Hladil, J. and Adamovic, J., eds, 2011, Miroslav Krs conference: time, magnetism, records, systems and solution. The 2011 Annual IGCP580 Meeting, pp. 60.

Koptíková, L., Hladil, J., Slavík, L., Èejchan, P. and Bábek, O., 2010b, Finegrained non-carbonate particles embedded in neritic to pelagic limestones (Lochkovian to Emsian, Prague Synform, Czech Republic): composition, provenance and Links to magnetic susceptibility and gamma-ray logs. In: Da Silva, A.C., Boulvain, F., eds, Magnetic susceptibility, correlations and Palaeozoic environments. Geologica Belgica, v. 13, no.4, pp. 407430.

Kozowski, W.and Sobieñ, K., 2012, Mid-Ludfordian coeval carbon isotope, natural gamma ray and magnetic susceptibility excursions in the Mielnik IG-1 borehole (Eastern Poland)_Dustiness as a possible link between global climate and the Silurian carbon isotope record. Palaeogeography, Palaeoclimatology, Palaeoecology, v. 339-341, pp. 74-97.

Machado, G., Hladil, J., Koptikova, L., Fonseca, P.E., Rocha, F.T. and Galle, A., 2009, The Odivelas Limestone: evidence for a Middle Devonian reef 
system in western Ossa-Morena Zone (Portugal). Geologica Carpathica, v. 60, pp. 121-137.

Michalik, J., Lintnerova, O., Wojcik-Tabol, P., Gazdzicki, A., Grabowski, J., Golej, M., Simo, V. and Zahradnikova, B., 2013, Paleoenvironments during the Rhaetian transgression and the colonization history of marine biota in the Fatric Unit (Western Carpathians). Geologica Carpathica, v. 64, no 1, pp. 39-62.

Michel, J., Boulvain, F., Philippo, S. and Da Silva, A.C., 2010, Palaeoenvironmental study and small scale correlations using facies analysis and magnetic susceptibility of the mid-Emsian (Himmelbaach quarry, Luxembourg). In: Da Silva, A.C., Boulvain, F., eds, Magnetic susceptibility, correlations and Palaeozoic environments. Geologica Belgica, v. 13, no.4, pp. 447-458.

Pas, D., Da Silva, AC., Cornet, P., Bultynck, P., Königshof, P. and Boulvain F., 2013, Sedimentary environments of a continuous Middle Givetian to Upper Famennian section from the fore-reef fringe of the Brilon reefcomplex (Rheinisches Schiefergebirge, Germany). Facies, v. 59, pp. 969990.

Potma, K., and Weissenberger, J., 2013, Carbonate lithofacies within a sequence stratigraphic framework: The Late Givetian to Early Frasnian of the Alberta Basin. IGCP 580-596 Core Session Guidebook, 31 pp.

Racki, G., Racka, M., Matyja, H. and Devleeschouwer, X., 2002, The Frasnian / Famennian boundary interval in the South Polish-Moravian shelf basins: integrated event-stratigraphical approach. Palaeogeography, Palaeoclimatology, Palaeoecology, v. 181, pp. 251-297.

Riquier, L., Averbuch, O., Devleeschouwer, X. and Tribovillard, N., 2010, Diagenetic versus detrital origin of the magnetic susceptibility variations in some carbonate Frasnian-Famennian boundary sections from Northern Africa and Western Europe: implications for paleoenvironmental reconstructions. International Journal of Earth Sciences, v. 99, pp. S57S73.

Shackleton, N.J., Hall, M.A., Raffi, I., Tauxe, L. and Zachos, J., 2000, Astronomical calibration age for the Oligocene-Miocene boundary. Geology, v. 28, pp. 447-450.

Sliwinski, M., Whalen, M. and Day, J., 2010, Trace element variations in the Middle Frasnian punctata zone (Late Devonian) in the Western Canada sedimentary basin - changes in oceanic bioproductivity and paleoredox spurred by a pulse of terrestrial afforestation? . In: Da Silva, A.C., Boulvain, F., eds, Magnetic susceptibility, correlations and Palaeozoic environments. Geologica Belgica, v. 13, no.4, pp. pp. 458-482.

Sliwiñski, M.G., Whalen, M.T., Meyer, F.J. and Majs, F., 2012, Constraining clastic input controls on magnetic susceptibility and trace element anomalies during the Late Devonian punctata Event in the Western Canada Sedimentary Basin. Terra Nova, v. 24, pp. 301-309.

Storme, J.Y., Devleeschouwer, X., Schnyder, J., Cambier, G., Ignacio, B., Pujalte, V., Di Matteo, A., Iacumin, P. and Yans, J., 2012, The Palaeocene/ Eocene boundary section at Zumaia (Basque-Cantabric Basin) revisited: new insights from high-resolution magnetic susceptibility and carbon isotope chemostratigraphy on organic matter $\left(\mathrm{d}^{13} \mathrm{C}_{\text {org }}\right)$. Terra Nova, v. 4 , pp. 310-317.

Vacek, F., 2011, Palaeoclimatic event at the Lochkovian-Pragian boundary recorded in magnetic susceptibility and gamma-ray spectrometry (Prague Synclinorium, Czech Republic). Bulletin of Geosciences, v. 86, pp. 259268.

Vacek, F., Hladil, J. and Schnabl, P., 2010, Stratigraphic correlation potential of magnetic susceptibility and gamma-ray spectrometric variations in calciturbiditic facies mosaics (Silurian-Devonian boundary, Barrandian area, Czech Republic). Geologica Carpathica, v. 61, pp. 257-272.

Weedon, G.P., Jenkyns, H.C., Coe, A.L. and Hesselbo, S.P., 1999, Astronomical calibration of the Jurassic time-scale from cyclostratigraphy in British mudrock formations: Royal Society London, Philosophical Transactions v. A357, pp. $1787-1813$

Whalen, M.T. and Day, J., 2008, Magnetic susceptibility, biostratigraphy and sequence stratigraphy: insights into Devonian carbonate platform development and basin infilling, Western Alberta, Canada. In: Controls on Carbonate Platform and Reef Development, SEPM Special Publication, v. 89, pp. 291-314.

Whalen, M.T. and Day, J., 2010, Cross-basin variations in magnetic susceptibility influenced by changing sea level, paleogeography, and paleoclimate: Upper Devonian, Western Canada sedimentary Basin. Journal of Sedimentary Research, v. 80, pp. 1109-1127.

Whalen, M.T., Osadetz, K., Richards, B., Kabanov, P., Weissenberger, J., Potma, K., Koenigshof, P., Suttner, T., Kido, E. and Da Silva, A.C., (eds.), 2013, Geophysical and Geochemical Techniques: A Window on the Palaeozoic World. IGCP 580-596 Programme with abstracts, 47 pp.

Wu, H.C, Zhang, S.H., Hinnov, L.A., Jiang, G.Q., Feng, Q.L., Li, H.Y., and Yang, T.S., 2013, Time-calibrated Milankovitch cycles fro the Late Permian. Nature Communications, v. 4, pp. 2452.

Zhang, S., Wang, X. and Zhu, H., 2000, Magnetic susceptibility variations of carbonates controlled by sea level changes - Examples in Devonian to Carboniferous strata in southern Guizhou Province, China. Science in China, Serie D, v. 43, pp. 266-276. 